\title{
Pragmatic Acts In HIV/AIDS Social Management Advertisements
}

\author{
Toyin Makinde (Ogun State, Nigeria)
}

\begin{abstract}
Studies on the social management of HIV and AIDS have focused on how awareness about HIV and AIDS has been created through organised and interpersonal communication. These studies have not investigated context-constrained language use in the advertisements on the disease despite the wide coverage and potential effectiveness of the public sensitisation about HIV and AIDS. This study, therefore, investigated the pragmatic features of language in selected HIV and AIDS management advertisements with a view to identifying the pragmatic acts of the language. Aspects of pragmatic act theory, noted for negotiability of meaning context based interactional situations was adopted for the research. All the 25 advertisements broadcast between December 2006 and June 2009, to all African countries on both private and government-owned television stations in Nigeria by an International non-governmental agency known as 'it begins with you' (YOU) constituted the data. Fifty-four utterances were generated from the adverts and were subjected to qualitative analysis and reported in simple percentages. Six pragmatic functions manifested in the advertisements: Co-opting and Projecting were realised through inference (INF), shared situational knowledge (SSK) and relevance (REL) to bring the audience into the war against HIV/AIDS. Encouraging and Emboldening were projected through SSK and INF to motivate the audience to go for HIV test and speak openly about the virus. Instigating was done using indirect speech act to empower the female against discrimination and stigmatisation. Advising was achieved through SSK and INF to promote fidelity and safe sexual behaviour. The analysis of YOU advertisements through pragmatic act theory presupposes that pragmatic functions were exploited by the advertisers to sensitise the audience, promote social ties and project into an HIV free generation.
\end{abstract}

\section{Introduction}

In view of the fact that some terminal diseases such as cancer, AIDS, and other related diseases are incurable, medical science has proved that if these diseases are detected on time, and well managed, the victims' life could be considerably spared to reasonable extent. This knowledge has propelled different countries to embark on rigorous campaigns against these killer diseases with a view of educating their people on some preventive strategies in the meantime, while further efforts are directed at producing drugs that can eradicate them successfully. One of such preventive strategies is creation of awareness about HIV/AIDS, mode of contact and spread. 
Although scholars from diverse academic fields have researched into various concepts relating to the discourse at hand, but only few studies have been done on this subject from a linguistic perspective. Among the few notable one are studies done by Kroger (2000), Leap (1991), Sontag (1991), Jacobs (1993). In essence, earlier researches conducted on HIV and AIDS have jointly asserted that there has been some form of awareness about the virus. However, the types of campaigns adopted, the effectiveness of the genre used in transmitting the information and the function of language as instrument of awareness, particularly advertisements have not been fully discussed. This is the focus of this study.

\section{Pragmatics of Advertising Communication}

Advertising can occur in diverse ways: either conventionally through the use of print media, electronic media, billboards and posters or through other unconventional ways like inscriptions on moving vehicles, clothing and even some underclothes. Lately, with the advent of the new information and communication technology, advertising is now relayed and transmitted on the Internet, a procedure known as "netvertising". Scholarship has also shifted to investigating this area.

Bovee and Areens (1982) present advertising as a persuasive tool used to endear a product, service or idea sponsored by some identified agents on to consumers. Vestergaard and Schroder(1986) identify two basic types of advertisements as commercial and noncommercial. Taflinger (1996) avers that there are several types of advertisements; these are straight announcements, testimonial advertisement and demonstration technique. The basic way to present a sales message that Taflinger (1996) also suggests, is to appeal to the emotions of the audience. He however hinted that in doing an emotional presentation, the advertiser must concentrate on other aspects of the consumer's bundle of values; this may be social, psychological, or economical. Odebunmi (2007) in corroborating advertisement as a means of persuading audience to accept products that are presented to them, further claims that adverts have been a strong determinant director of social and political events in every society.

Pragmatically, from linguistic perspective, the concept of advertisement can be explained to mean an act initiated from a source i.e. the speaker, who relays a message that is expected to perform certain functions on the target audience (hearer). In essence, the advertisement is paid for in order to achieve intention of the speaker. Hence, every advertisement is directed at certain audience who would approve of the product by agreeing with the propositions stated as benefit(s) derivable from the product, and thereby endorse its usage by purporting to make a purchase or have a change of attitude. Thus, the perlocutionary effect of the advertisement is said to have been achieved at this point.

\section{The Data}

The data for this research are twenty five advertisement copies packaged and sponsored on the Nigerian Television Authority from December 2006 to time of this research, by an International non-governmental agency, African Broadcast Media, popularly tagged "It Begins with You" (YOU). These adverts are broadcast to all Africa countries on the electronic media. These media-led HIV and AIDS public education effort linked Africans together; this quality informed our choice of the HIV adverts. 
Also a set of six (6) structured interviews was conducted on fifty (50) subjects in Ogun State being the population under study. Ogun State was chosen because it was declared as having the largest HIV cases in south western Nigeria as at 2007 when this study commenced (OGSCA 2007). A purposive sampling technique was used to enable the researcher to get an unstructured population. This was done with a view to further understand the advertisements from the audience's perspectives.

\section{Theoretical Orientation - Pragmatic Act Theory}

The data at hand are television advertisements. These adverts were chosen because they allow hearers to actually see and match utterances with actions and settings of the communication events under view. These advertisements portray a life similitude of normal interactional situations. The audience are not just left to create images of what they might think was the actual setting or context but are furnished with both utterances and contexts. This is an example of Kesckes' (2010) submissions that meaning occurs when utterance matches situation of context. This informed the use of Mey's pragmatic acts theory which indicates that speech acts is not just about speakers but how their utterances are constrained by context of the speech events. We shall therefore examine the theory as it relates to the data.

The theory of pragmatic act does not explain human language usage by starting from the words uttered by single, idealised speaker, rather 'it focuses on the interactional situation in which both speaker and hearer realise their aims' (Mey 2001: 212). Instead of looking for what a word could mean in isolation, the situation in which the word is expressed is invoked to explain what is actually said. The language we use, particularly the speeches we utter, are entirely dependent on the situation in which the acts are produced. Mey (2001) opines that pragmatic acts are based on language use as constrained by the situation, not as defined by syntactic rules or by semantic selection and conceptual restrictions. All speeches are in essence context-situated. (cf. Scheghoff (1987:208), Goffman (1972), Hymes (1964), Fowler (1996) and Adeniyi (1997) for further classification on context.)

A speech act is never just an act of speech, but something that should be considered as the total situation of activities within which an utterance occurs. The emphasis here is not just on rules guiding individual speech or utterance, but principally on characterising a typical pragmatic act as realised in a given situation. Every action realisable through words is a 'pract' but no two acts will ever be identical. For instance, Hanks (2006) explains that different situations can lead to declaration of war. In other words, wars can be caused by different factors. Therefore, the same set of utterance, word for word will mean different things at different occasions. (cf. Kurzon (1998: 587) Hanks (2006))

The emphasis on pragmatic acts is no longer on describing individual acts as it were for Searle (1965), conversely, the individual speech acts make sense only when analysed in the context of occurrence. Hanks (2006) corroborates this by stating that 'meaning arises out of the interaction between language and circumstances, rather than being encapsulated in the language itself'. In essence, the view of Hanks is that language alone cannot give a comprehensive meaning of an utterance, but meaning can be fully achieved when the circumstances in which an utterance is produced is considered along with the utterance. Odebunmi (2006: 77) further expatiates on this by stating that what determines a "pract" are 
solely participants' knowledge of the interactional situation and the potential effect of a pract in a particular context.

Figure 1 below is a model propounded by Mey (2001) to explain the concept of situated speech act known as pragmeme.

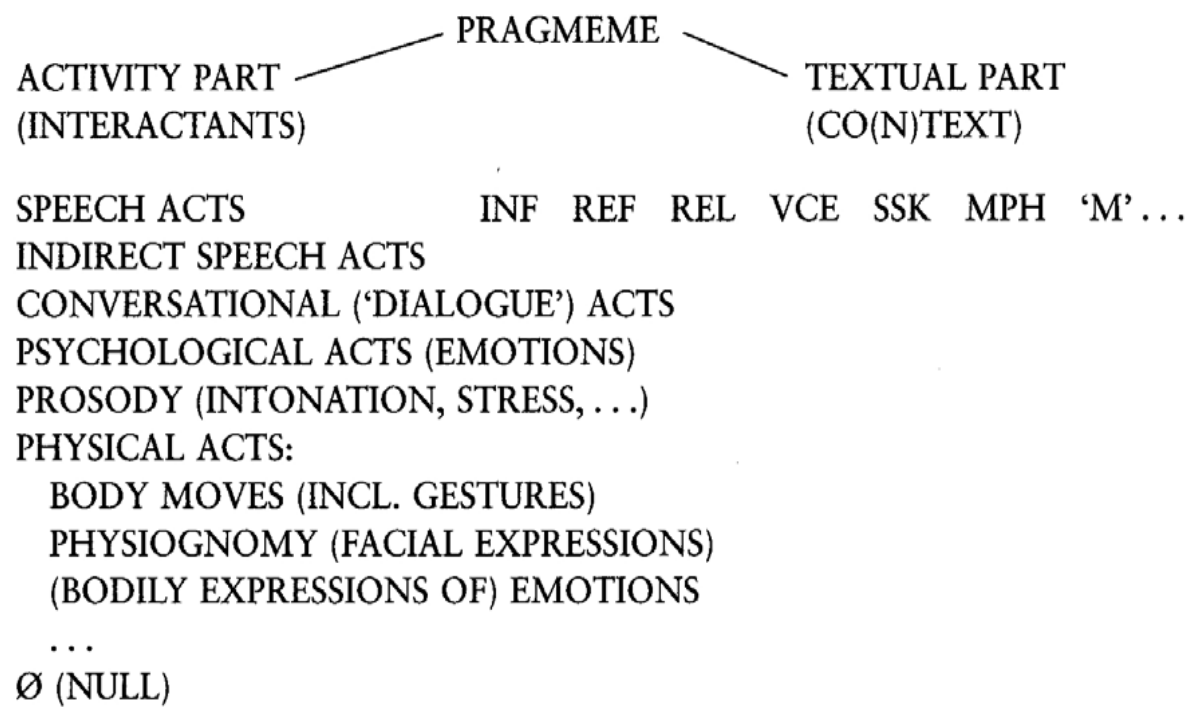

PRACT

ALLOPRACT

PRAGMEME, PRACT, ALLOPRACT

Figure 1: Model of Pragmatic Acts (Mey 2001: 222)

In any speech event as indicated in the model above, it shows that a speaker's utterances alone do not reveal his/her intentions when speaking, but other paralinguistic features do combine adequately with the utterance to lead the hearer to successfully realise the meaning of the intentions of the speaker. These utterances are always in two parts; one is the textual part and the other the activity part. The textual part is determined by the context as well as the text (utterance) that is intended. This can be achieved through the use of various choices that range from 'INF' inference, 'REF' reference, 'REL' relevance, 'VCE' voice 'SSK' shared situation knowledge and 'MPH' metaphor. All these elements work together to enable the interlocutors to understand and reach their desired interactional goals.

On the other side of the divide of pragmeme is the activity part. These are non-verbal cues which come in form of body gestures, facial expressions, prosodies etc. If these non-verbal cues are adopted during any interaction, they further assist in relaying the speaker's intentions. Hence, interlocutors are allowed to make choices from one or more of the items on the left in order to realise their intentions, otherwise the categories are filled with null.

Therefore, due to the composite nature of the selected advertisements in which action and utterance are combined to reveal the intentions of the speaker, investigation cannot be best achieved with speech act theory because speech act deals with utterances only. However, when the utterance carries with it other supporting acts such as gestures, intonation, body postures etc., on which it essentially depends for success, it requires a more demanding theory 
like pragmatic act. These other extra linguistic elements, Kesckes (2010) suggests, will have bearing on the speakers and the hearers. Our investigations in line with Mey (2001), reveal that it is not possible for speakers to engage in all the elements indicated in the activity part at all times, hence a modified model of Mey's theory below was produced and applied to this study.

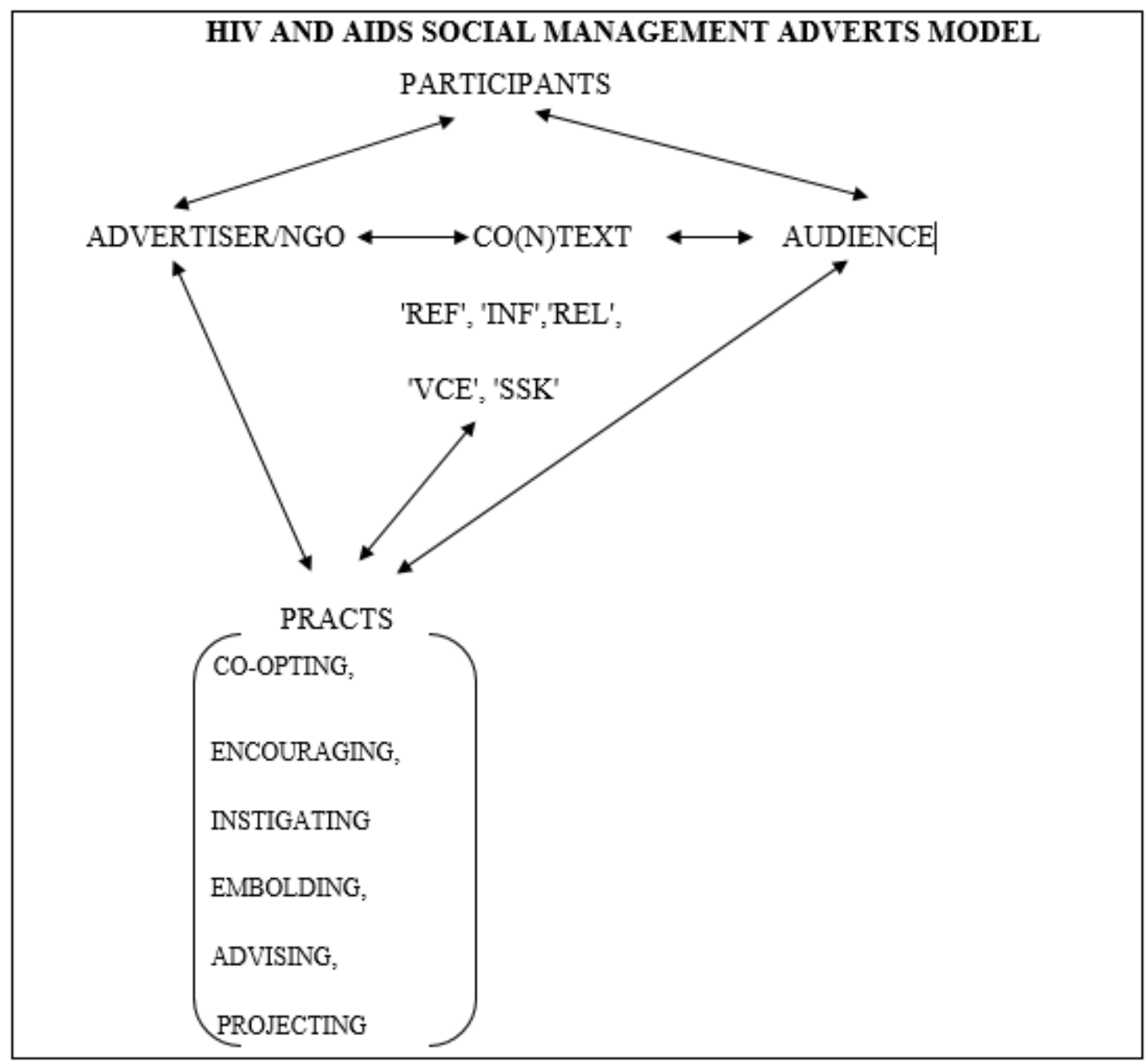

Figure 2: Modified Model of Pragmatic Acts

The verbal utterances will be scrutinised to determine types of pragmatic acts while the contexts will be pictures and activities shown in the advertisements setting as well as their exospheric reference to the African society and culture.

\section{$5 \quad$ Review of Related Literature on HIV and AIDS}

A great number of studies have been carried out on HIV and AIDS by scholars, each using diverse approaches. However, these few studies from linguistic perspective, have not actually investigated language use pragmatically in the advertising discourse. Wood and Kroger (2000) analyse verbatim transcriptions of some discussion groups using a psychosocial discourse analysis approach to examine what people do with their talk on events and phenomena of HIV and AIDS in an interpersonal exchange. This approach, the duo remark, casts some light on obscure dysfunctional discourses that are common in individuals' practices. It also helped to reveal how discourse is structured to perform various functions and 
achieve effects or consequences relating to HIV/AIDS. The chosen method which is a psychosocial discourse analysis has pragmatic effect rather than analytic relevance. This is because it contributed to strategies that helped to modify individual's health attitudes and practices. It also suggested changes to how people should talk about such issue.

As a follow up, Leap (1991) explains that in order to understand how people talk about AIDS, one must study the language use in such communicative instances and how different linguistic styles may affect communication. In Namibia for instance, a study was conducted by Mariel, Kengmo, and Lurie in 1993 to find out how people can be encouraged to discuss human sexuality openly, an openness that would reduce risky behaviour and promote safer sex habits. The Namibians' study suggests promotion of indigenous language and use of street drama to communicate AIDS messages to the people. A similar project conducted in Cameroon initiated a community-based dance and music group-popular theatre, through which AIDS education and prevention messages were being communicated to people (Mariel/Kengmo/Lurie 1993).

Sontag (1989) indicates that metaphor has constituted a crucial brick in people's social communication discussion. This she reports is used to enable the people cope with new and frightening situations. Sontag further observes that the people also generalise from their previous experiences to express new feelings and by using metaphors as a rational way of doing this. She however reviews her previous opinion of metaphors as something generally perceived as evil, but now establish that people sometimes need metaphors in order to think, interpret and communicate. Although she warned that some metaphors should be abstained from particularly when used with public health issues, this is because stigma generated from certain metaphors which are used to cover up their health condition are sometimes worse than the illnesses themself. Metaphors can give very tangible consequences, especially perhaps as creators of "spoiled identities," a concept referred to by Goffman (1993).

In a recent study by Makinde (2013), insight from perlocutionary analysis of some selected advertisement on HIV reveals that language used in the advert is designed to have subtle, compelling authority and immediate impact on the audience. This style has created greater awareness about the virus. Her investigation further indicates that the choice of language use in the examined radio drama specifically package for HIV/AIDS campaigns are significant in creating awareness and solicits support for people already living with the virus.

As a collaborative effort at further shedding light on solving problem of HIV/AIDS, this research is interested in how language functions in the selected social management advertisements under study.

\section{$6 \quad$ Analysis and discussion of findings}

The setting in the advertisements, as well as the exospheric reference to the society and African culture at large are taken as the context in this analysis. In applying the model of Mey (2001) adopted by Odebunmi (2003) and adapted for this study to our discussion, the practs found in this genre of medical discourse are: co-opting, encouraging, instigating, emboldening (used specially in this study), projecting, and advising. These are accounted for qualitatively and in simple percentages as they appear in the HIV and AIDS management adverts below. 


\begin{tabular}{l|c|c}
\hline Pragmatic Function & Frequency & Percentage \\
\hline Co-opting & 23 & $42.6 \%$ \\
\hline Projecting & 13 & $24.1 \%$ \\
\hline Encouraging & 11 & $20.7 \%$ \\
\hline Emboldening & 4 & $7.0 \%$ \\
\hline Instigating & 2 & $3.7 \%$ \\
\hline Advising & 1 & $1.9 \%$ \\
\hline Total & 54 & $100 \%$ \\
\hline
\end{tabular}

Table 1: Pragmatic Acts in YOU Adverts

\subsection{Co-opting as a Pragmatic Act}

Co-opting is a process through which people who were not part of an earlier selection are invited on board because of certain qualities that they possess. Co-opting which are the majority practs used in advertisements are used to seduce the viewer or reader. This is done to subtly incorporate the target audience into the campaign, and to prevail on them to feel concerned and participate in reducing the spread of the virus to a manageable level. This pragmatic act which accounted for $42.6 \%$ of the discourse units, could also be interpreted to reflect the intentions of the advertisers in eliciting support in the following ways:

(i) To give support to people living with HIV/AIDS;

(ii) To remove stigmatisation;

(iii) To promote self-protection;

(iv) To give hope to people living with the virus.

\subsubsection{Co-opting to Promote Support}

Co-opting the audience to give support to people living with HIV virus was introduced to gain audience's attention and seek their involvement in making the campaign a success. This is indicated in the Example 1 (Ex) below,

(1) You can make it possible by sharing responsibilities.

The referent 'you', a second person plural or singular pronoun, refers to the audience, i.e. any individual or group of people that has contact with the advertisements. The essence is to sensitise as many of the audience as possible to join in the fight against the spread of HIV and AIDS.

Sharing responsibilities in the context of the advertisements is an admonition to indicate that the audience must be responsible for their actions and contribute to each other's welfare. This pract encourages the audience to take precautions by being faithful to one faithful partner, to use condom, and when necessary, do outright abstinence. This plea also elicits support for people already living with the virus henceforth PLWHA. This is achieved by drawing inference from social bounds and family ties that already exist in African society. 
Co-opting as a pragmatic act is further buttressed by the constant repetition of the pay offs. Example 2 suffices.

(2) It begins with you.

'It' in example 2 is a pointer to the intention of the advertiser i.e. the ability of the referent you to eradicate HIV. Example 2 is also an indication that every approach to the management of the HIV/AIDS advertisements begins from the individual who is expected to influence his/her nuclear family and by extension the society at large. This 'It', a third person pronoun, stands for some of the major intentions of the advertiser which are:

- Creating awareness about the virus,

- Living a healthy live devoid of HIV virus,

- Maintaining healthy sexual habit for adults,

- Abstaining from sex for youth and unmarried until the right time,

- Nursing the prospect of an HIV free generation, etc.

Co-opting to gain support from the audience is further strengthened in the Example 3 below.

(3) So that we can successfully fight it together.

Example 3 above is a persuasion for the audience not be judgmental in matters of HIV and AIDS, and in particular not falling into the well-known moralistic trap of regarding the disease as a punishment for people's sin. In the Example, the first person plural pronoun - We and the verb fight are linked with co-opting. 'We' is another open invitation to the audience to be enlisted in the campaign against HIV and AIDS. In as much as it takes two people to perform the act of having sex, it also demands that the two must agree together to take necessary precautions.

Also, the fight in the context of utterance of Example 3, has reference in resisting the virus, thereby controlling the spread. Fight can also come in form of taking precautions when having sex, knowing one's HIV status, as well as speaking openly about the virus in order to educate other members of the society. This aspect of open discussion about the virus is very important to the discourse because it intends to prevent or stop bulk passing on which gender is more prone to the virus infection or the myth that a particular gender is a common carrier. This brings to bare one of the advocacies targeted at gender equity.

The next example of pragmatic act promotes gender equity.

(4) You can make it possible by understanding that men and women are created equal.

The act in Example 4 above with exospheric reference to the larger society is very germane to the discourse. This is because Africans have a set of beliefs that make a woman inferior to a man. One of such beliefs is that a woman is more prone to having more diseases and in some instances responsible for all medical problems, like infertility, in a home. This pract which is also an appeal to urge men to change their views about the position of women in the home and the society at large, also attests to the fact that both sexes have equal chances of contacting HIV if not protected. Therefore both sexes have equal volume of responsibility at eradicating myths, and broadcasting facts that surround the spread of the virus. In conclusion 
co-opting is done to gain the support of the audience by encouraging whosoever comes across the adverts to be part of the campaign. Every individual should start by living a healthy sexual life.

\subsubsection{Co-opting to Remove Stigmatisation}

Casting our minds back to Mey (2001) in studying practs, we support the position that pragmatics are not concerned with matters of grammatical correctness or strict observation of rules exclusively, but with the understanding that each participant has in the context of the utterance. Charles (2001) supports this by claiming that advertisers purposefully infringe on the rules of language to make product advertisements more effective. Hence, Example 5 and some subsequent ones are not complete sentences but phrases that function to make known the intentions of the advertiser in a style common to all advertisements.

(5) By deciding not to be part of the problem but solution

In Example 5 above, the intention is to appeal to audience not to complicate the problem of people who have already tested positive to HIV virus. Stigmatisation is a situation in which victims are dishonoured, rejected and blamed for testing positive to HIV. An infected person already suffers a great psychological trauma. More so, the attendant rejection by friends and family members most of the time worsen the case. This usually makes most victims lose hope and give up fighting to live. Therefore, enlisting against stigmatisation is done by co-opting all the audience into solving this major problem.

The audience, through Example 5, are thus encouraged not to be part of the problems such as discrimination, stigmatisation, engaging in indiscriminate sex, etc. but are expected to be agents of change that will bring about solution to the problems listed above. This can be done by going for test on time, helping friends and family to make right choices, taking necessary precautions when needed and providing succour to people already down with the virus.

The final example to be considered on why audience are co-opted is to harden them against stigmatisation. This is done with the intention of encouraging people to speak openly about the virus and declare their HIV status without fear of rejection.

(6) Imagine the world that encourages people to speak about HIV/AIDS.

The world projected in Example 6 is a society that promotes freedom of speech, and encourages PLWHA to speak openly about HIV and AIDS and on how they contacted the virus without fear of rejection, intimidation and discrimination from friends and family members. This conforms to a study that was conducted in 1993 in Namibia, which sought to find out how people can be encouraged to discuss human sexuality openly, an openness that could reduce risky behaviours and promote safer sex, such as the use of condoms. The act in Example 6 solicits support from family and friends and pleads with them not to reject the sick, but care for them in love.

The intention of the advertisers in encouraging people to speak out about HIV and AIDS is to break the tradition of silence on sex related issues. In Africa, sexual matters and issues surrounding intimacy are not discussed openly; in fact, some sensitive body parts are referred to with euphemisms. Odebunmi (2011) affirmed that sex-related conditions are affiliated with cultural norms so much that many Yoruba people prefer sex related issues and condition to be 
discussed with 'camouflages'. However, contrary to this notion, the intention here believes that people will have full knowledge about the contact and spread of the virus and that some erroneous belief about HIV will be removed if people speak openly about sex and sex related issues. This perhaps explains the high frequency of the practs as exemplified by Examples 7 and 8 .

(7) That world is possible.

(8) It begins with you.

That world is possible in Example 7 is a pointer deictic that refers to a world free of HIV, a place where friends and family care for the sick. A world free of HIV and AIDS is possible again and people living with the virus can live a normal life. It is hoped that the fear of rejection will be removed if the referent 'You' in Example 8 starts by giving support to the sick, by taking care of them and knowing that mere touching or friendly associating do not make one contract the virus. The two Examples above have very high frequency of usage in the selected discourse. This may be because the pragmemes, when joined together (as Ex 7 and Ex. 8 always follow one another), perfectly reinforce the voice of the sponsors.

\subsubsection{Co-opting as a Means of Protection}

Co-opting is further done by redirecting the attention of the youth from premarital sex and to hard work in order for them to achieve their dreams. This act connotes prevention. Also, the advertiser catches up on the advantages of the effect of peer pressure to sensitise the youths. Peer pressure influence as demonstrated in the motion picture, where a group of boys wanted their friend to have unprotected sex, suffices. Given that peer pressure can lure the youth to engage in vice or virtue, the youths are encouraged in Example 9 to shift attention to working toward achieving their dreams. Failure to do this might lead to grievous consequences of being infected.

(9) And talking together about the consequences of our action.

In Example 9, talking together entails educative interactions through which everybody understands the facts and myths that surround the contact and spread of the virus. Also in 'talking together', the audience get to know that sharing of sharp objects like needles, blades, unscreened blood, body fluids and reckless sexual habits are principal ways of contacting the disease; and that hugging, hand shake, sharing of plates and cutleries cannot transfer the infection.

\subsubsection{Co-opting to Give Hope to People Already Living with the Virus}

Aside from talking together, the audience are enlightened about the consequences of their actions. Talking together will promote the importance of their self-will by encouraging sexual fidelity, self-discipline, being informed about dangers of premarital sex and the risk of having multiple sexual partners.

(10) By dreaming big and working to achieve your dreams.

The consequences of our actions is also emphasised in Example 10 above; actions such as illicit sex, unprotected sex, sexual infidelity, having more than a sexual partner or premarital sex are the proposed actions that can mar the life of the youth. This will in turn result in other 
problems like: contacting sexually transmitted diseases, teenage pregnancy, and abortion. The youth are thereby encouraged to know that every action has its consequence. So, rather than getting involved in the above listed risky behaviours, the audience are persuaded in Example 10 to shift attention to more profitable venture that will enhance their future.

\subsection{Projecting as a Pragmatic Act}

Projecting functions as the second main pract in the HIV and AIDS management advertisements under study. This pract represents $24.1 \%$ of the total discourse. Projection is a prediction or a longing for better days ahead: a state of tranquillity, where things will return to normal as they were before the outbreak of the virus. Arai (1977) recommends that a part of what makes successful advertising copy persuasive can be explained using relevance theory's notion of mental profit (cognitive effects) for the listener or the reader. In projecting through persuasion, what the advertiser is proposing is for the audience to recall from their cognition a generation devoid of the virus which had formed part of their upbringing experiences.

The various practs used here are directed towards a longing that represented the internal fear of the (audience and) advertisers. The voice here is that of the speaker and hearer, but made manifest in the advertisement through the sponsor. This projection in Example 11 calls for immediate action which begins with you that is from anyone who comes in contact with the advertisement, as in the case of co-opting, but goes a little further to state what is expected after the work starts from the referent you.

(11) Imagine the possibility of an HIV free generation.

Example 11 is a projection into a virus free generation that everybody desires. It is intended to raise hope for a better future, while Example 12 gives inspiration to the sick. This pract proposes to encourage the sick and the infected that hope is not lost. The voice of the advertiser inspires the audience to know that even if the menace could not be totally eradicated for now, at least those who are sick should not be rejected. They must still be cared for by friends and family. Loneliness and rejection are some of the reasons why people shy away from checking their HIV status. Therefore, Examples 12 and 13 are relevant to allaying the fear of the audience.

(12) Imagine the world where the sick are not rejected but are cared for in love.

The sick, in the context of Example 12 are people who are infected with the virus or those that are already down with a full-blown AIDS. For the lack of adequate enlightenment on how AIDS is contacted, apart from through unprotected sex from infected persons, majority of the audience are apprehensive that a touch, sharing of plates or even something trivial as sitting with an infected person can transfer the virus to them. People already living with AIDS (PLWHA) are hence often neglected and many of the victims die of loneliness and rejection rather from the infection itself. This utterance in Example 12 is an indirect speech act which represents the voice of the sick begging for attention. The two pragmemes already discussed call for support, care and affection for PLWHA. The next three practs of projecting further substantiate an appeal for an HIV free generation.

(13) Imagine a world where people have the support of their family and friends.

(14) Imagine the world with friends encouraging each other to make right choices. 
(15) Imagine when the young will have access to true and trusted friends.

These three examples above in Examples 13-15 are allopracts of the same pragmeme. They are projections with advocacy for trust, friendship, making right choices and giving support wherever it is necessary. They are scripts of the socio-cultural set up of the environment. They draw inference from African culture, which believes in oneness and family support. Friends are essential to certain decision at certain age. The peer group influence is particularly worthy of note in this instance because friends can lead one to make right or wrong decisions. They can also make or mar one's future. This is perhaps why emphasis is laid on friendship.

The projections here are in three parts. Example 13 is for a perfect society where everybody cares for one another. The voice of the sponsor here appeals for love, affection and respect for one another. Example 14 reinforces the first by projecting into a future where friends will encourage one another to make good and right choices. Good choices for the youth will be to concentrate on their studies, engage in developmental projects, abstain from premarital sex, and if they must have sex, use condom. Finally, the youth are encouraged in Example 15 to think of how to be a true and trusted friend while they are also dependable to others.

\subsection{Encouraging as a Pragmatic Act}

The next set of practs functions as encouraging. These accounted for $20.1 \%$ of the total discourse in the selected adverts. These practs strengthen the audience to go for the screening /test, speak about the virus, and audience are encouraged not to criticise PLWHA. It is also an advocacy to motivate the youth to redirect their initiative and ingenuity towards achieving better standard of living, away from casual and pre-marital sex.

(16) Imagine the world when young people use their initiative and ingenuity to tackle all challenges and invent new ideas.

The utterance in Example 16 above, when analysed within the context of the motion pictures and the utterance in the advert, combine to indicate a clarion call for the youths to take up the challenges, to help PLWHA, as well as to invent new treatment procedure. In the advertisements contexts, youth were seen playing football and winning the match, some studying together, others were looking up to some African icons like Madiba, Desmond Tutu and Former President of Nigeria, Obasanjo, who was seen among fresh graduates from the university. Some other youths were presented as being busy aiming to be like the Republic of Benin popular music icon, Angela Kidjo and the Kenyan marathon race runner among others. The intention here is to lure them into more profitable activities away from casual sex.

This is an attestation to a view expressed by Williamson (2006) that in decoding advertisements, one must not concentrate on just the overt message of the advert but also take interest in the covert message of the advert that is captured in the image. The new ideas as suggested by the utterance in Example 17 can come in form of researching to discover new drugs that will cure victims of the virus, or in form of inventing more effective preventive drugs and management strategies. Through the pragmatic act of encouraging, Examples 17 and 18 further suggest useful strategies to achieving that goal.

(17) Imagine the world where young people with dreams live a healthy life and work hard to achieve their goal. 
(18) A world where young people are encouraged that knowing their status is the right step to secure their future prospect.

Example 17 reiterates that only healthy people can work to achieve their dreams. Dreams are childhood vision of what an individual desires to become or plans to achieve in life. Dreams can also die if not well pursued. Similarly, Example 18 encourages the youths, who are a regarded as the strength of the nation to diligently pursue their dreams, otherwise when neglected will have grave consequence on the nation.

\subsection{Emboldening as a Pragmatic Act}

The act next in hierarchy is emboldening (used specially in this study). This accounted for $7.4 \%$ of the sum total of pragmatic acts under discussion. Emboldening functions to give confidence to the audience who may be scared to be tested. They appeal to the psychology of the audience. This is very obvious particularly when the communicative action is an instruction that requires a hearer to perform certain acts, which are intended to change the hearer's mental state in some way. The goals that an utterance achieves, or is meant to achieve, are called perlocutionary effects by Austin (1962). Emboldening is used to further allay fears associated with the result of HIV test particularly if the audience is scared of testing positive. The following Examples suffice.

(19) And no one is afraid to get tested.

(20) And everyone understands that stigma drives HIV.

The two Examples, i. e. 19 and 20, appeal to the emotion of the audience. They indirectly speak about the fear of the audience. These statements are relevant to the present situation where people, for fear of the outcome of HIV test, usually deny the knowledge of its existence as a way out. No one is afraid to get tested in Example 19, may not be totally true because it is not the voice of the audience but that of the sponsors and the stakeholders trying to psyche the audience to get tested.

Example 20, like 19, indicates that everyone understands that stigma drives HIV. The fear of stigmatisation does not encourage people to be tested. This lack of knowledge about one's HIV status can affect others. It is this challenge that the practs propose to resolve. The metaphor that stigmatisation drives HIV is hinged on the fact that the fear of rejection, a consequence of having tested positive to the virus, may spur victims to seek revenge from the society that has rejected them by deciding to be having indiscriminate sex. The essence of this pract, therefore, is to strengthen the audience against stigmatisation. The above pract emboldening - has a link with the next pract which is instigating.

\subsection{Instigating as a Pragmatic Act}

Instigating can be interpreted as being empowered to work against someone or something, or to give a boost to one's ideology. Instigating is subtly and sparingly used in the selected advertisements. This pract accounted for just $3.7 \%$ of the total sum. This is done to propel the women folk to reject intimidation, threats and forceful coition against their will. The women are also heartened to brace up to achieve whatever dream they desire. It is also a way of promoting gender equity. This is reflected in Examples 21 and 22 below: 
(21) You can make it possible by understanding that men and women are created equal.

(22) No matter your sex, you can achieve whatever your dreams are.

The pragmatic functions of the utterances in Example 21 and 22 are to encourage both sexes not to see one gender as inferior to another and that the women, in particular, should not allow men to take advantage of them. This is further buttressed by emboldening the female in Example 21 against intimidation, but be encouraged as in Example 22 to strive at reaching their set goals. In the context of the advertisements, the settings show that the female gender too can rise up to achieve their dreams by getting qualified and practising whatever career they propose to follow.

The pract is also to urge parents with all female children to develop confidence in them by helping them to pursue a career instead of pushing them into early marriage. In the advertisement, an all-female family was projected hosting people at the graduation party of their daughters from school of aviation. This act is to embolden other families who may be in the same boat not to give up on their girls, after all, if you educate a girl you have succeeded in training a whole nation.

\subsection{Advising as a Pragmatic Act}

Even though advertising is a genre under counselling, the act of direct advising is the least used act. It accounted for only $1.9 \%$ of the acts. Advising is a way of persuading the adult audience to be faithful in their relationships as well as show respect to their partners/spouses.

(23) Be honest and show respect in all relationships.

Honesty, in this context of Example 23, is an indication of faithfulness to one's partner, abstinence from extramarital affairs and use of condom for men having more than one wife. It is an admonition particularly for the married to respect their marital vows and keep away from extramarital affairs. This is particularly relevant in Africa where men measure their prowess and wealth through the number of wives and concubines they can service. This pract is targeted at protecting the faithful or innocent partner from infection that the unfaithful one may contact through infidelity.

\section{Conclusion}

Beyond filling the knowledge gap, this research has also opened up the HIV and AIDS social management advertisements genre from pragmatic perspective and has discovered that HIV and AIDS social management advertisements are context sensitive. It has made Mey's pragmatic act theory more explicit and has extended this theory to incorporate HIV advertisements discourse. Also this research has used pragmatic theory to help explain and perhaps solve a prevailing a social health problem by combining visual elements in the discourse to explain verbal utterances. Finally, this research may have sociological effect on resolving a topical issue in Africa. 


\section{References}

Arai, Satomi: (1977): "An Analysis of Information Content in Television Advertising". Journal of Marketing 41/1: 50-53.

Austin, John (1962): How to do things with words. Oxford: Clarendon Press.

Bovee, Catherine/Williams, Arens (1982): Contemporary Advertising. Home Wood: Irwin.

Hanks, William (2006): "Context, Communicative". In: Mey, Jacob (ed.) (2006): Concise Encyclopedia of Pragmatics. Amsterdam etc.: Elsevier.

Jacobs, Anon (1993): HIV/AIDS in Namibia: Behavioral and Contextual Factors Driving the Epidemic. Ministry of Health and Social Services.

Kroger, Fred (2000): "Preventing HIV Infection: Educating the General Public". The Journal of Primary Prevention 12/1: 7-17.

Leap, William (1991): "AIDS, Linguistics and the Study of Non-Neutral discourse". Journal of Sex Research 28: 275-287. www.jas.sagepub.com, accessed August 7, 2014.

Makinde, Toyin (2012): "Interactive Aspect of Vagueness in HIV/AIDS Management Radio Drama". International Journal of Arts and Culture in Society 4/1: 91--97.

Makinde, Toyin (2013): A Pragmatic Investigation of HIV/AIDS Social Management Advertisements in Ogun State Nigeria. MPhil Dissertation, University of Ibadan, Nigeria.

Mey, Jacob (1998): Concise Encyclopedia of Pragmatics. Amsterdam etc.: Elsevier.

Mey, Jacob (2001): Pragmatics: An Introduction. Oxford: Oxford University Press.

Odebunmi, Akin (2010): "Ideology And Body Part Metaphor in Nigerian English". Review of Cognitive Linguistics 8/2: 272-299.

Odebunmi, Akin (2011): "Concealment in Consultative Encounters in Nigeria Hospitals". Pragmatics 21/4: 619-645.

Sontag, Susan (1989): AIDS and Its Metaphors. New York: Farrar, Strauss, Giroux.

Taflinger, Richard (1996): An Overview of Advertisement. Belmont. 